MARYNA SHEVTSOVA ${ }^{1}$

FRIEND OR FOE?

Foreign donors' role in the formation of civil society in Ukraine

DOI: 10.18030/SOCIO.HU.2017EN.53

\title{
ABSTRACT
}

For a long time, civil society in independent Ukraine lacked visibility and seemed passive and underdeveloped. Yet lately foreign observers have defined civil society in Ukraine as the richest in the former Soviet Union in terms of the number and variety of organizations. In the aftermath of the Revolution of Dignity, as the state institutions are unable to perform their basic functions, civil society organizations (CSOs) have been compelled to take over some of their duties, getting involved into multiple spheres of public life, such as volunteering in the army, crowd-funding for internally displaced people and military needs. They are particularly strong in advocacy for reforms and acting as watchdogs of institutional change. However, while having proven its resilience in crisis, civil society in Ukraine still shows low sustainability and a high level of dependency on foreign donors.

Having acknowledged the positive role of foreign donors in the development of national civil society, the present article goes beyond this one-sided evaluation and answers the following questions: How do foreign donors influence Ukrainian CSOs working with civic participation and human rights advocacy? What are the main obstacles the CSOs face on the way to full independence and sustainability in post-Euromaidan Ukraine in the years 2014-2017? Drawing on the empirical data collected through the analysis of major national media sources and social media, participant observation, and interviews with civil society actors, policy-makers and foreign donors' representatives, this article argues that the role of foreign donors may be more complex than the way it used to be portrayed, as it should be assessed in the context of domestic social and political dynamics. The failure to do so may lead to unintended consequences and render previous achievements null.

Keywords: civil society, Ukraine, foreign aid, civil society organizations

1 PhD. TERGO, LGBT parents organization, Kyiv Ukraine. Berlin Graduate School of Social Sciences, Humboldt University, Berlin. Institute for Euro-Atlantic Cooperation. 
MARYNA SHEVTSOVA

\section{FRIEND OR FOE?}

Foreign donors' role in the formation of civil society in Ukraine

\section{INTRODUCTION}

External observers have recently defined Ukrainian civil society as vibrant and dynamic, experiencing a persistent rise after the so-called "Revolution of dignity" in 2013-2014 (Freedom House 2017). Indeed, Ukrainian society, in the times of antigovernment protest referred to as the "Revolution of Dignity" or "Euromaidan" and its aftermath, has seen the most significant mass mobilization since Ukraine emerged as an independent state in 1991 and the Orange Revolution in 2004. Even before the Euromaidan, Ukraine's civil society had shown some potential for being a driving force for the country's social and political transformations. The success of civil society organizations (CSOs) with toppling the corrupt president, Viktor Yanukovych, and forming a new government including leaders who emerged in the times of the protests, attracted the attention of international donors. They have for quite some time been nurturing local CSOs by various grants, exchange and technical support programs mostly coming from the West. In order not to leave Ukraine helpless in facing challenges of post-revolutionary times, bilateral donors such as the USA, the EU, Japan, and many others, as well as numerous international organizations have stepped up assistance, sharply increasing support and allocations (United Nations Ukraine 2017).

The presence of Western support and Western resources, as well as their influence on and importance for Ukrainian civil society organizations are obvious. Apart from the financial support coming to Ukrainian CSOs, a growing number of young Ukrainian politicians are Western educated (in contrast to the older generation educated in the Soviet society), heading to the EU or to the USA to attend schools, workshops, and other educational events, thereby forming a new and "democratic" mindset. In addition, Western countries put direct pressure on the Ukrainian government. Censor.net quotes Ukrainian MP Svitlana Zalishchuk, a young journalist and activist elected to parliament after the Euromaidan, maintaining that "70 percent of what has been accomplished so far has only been possible thanks to international pressure." (Lozovsky 2016). In other words, the positive view on the impact of Western states and international organizations on the general situation in Ukraine and development of local civil society is currently the dominant discourse in the Ukrainian public sphere.

At the same time, over the last couple of years blaming for national problems international organizations that support local non-governmental organizations has turned into a Central and Eastern European trend. Russian President Vladimir Putin was the first to shut down a number of donor organizations labelled as "foreign agents." This was followed by actions in CEE countries, with the Hungarian Fidesz launching a full-on offensive 
against NGOs that received funding through the EEA and Norway Grants program, and later attacking NGOs and Central European University related to George Soros. Similarly, the conservative government in Poland has passed a law to set up a body to control the allocation of foreign funding to NGOs operating in the country (DW 2016). The arguments of the ruling groups to justify restrictive actions targeting foreign donors are usually the threat these organizations allegedly pose for the country's independence and the inadmissibility of other international actors' interference in national politics. Considering that this kind of justification is coming from governments that are becoming more and more authoritarian, their accusations cannot always be seen as reasonable or fair. No scholarly or non-academic literature has suggested any objective evidence for claiming that international organizations and Western countries have a negative impact on democratization processes in third countries or that they pose a threat to these states' independence.

However, it remains to be questioned whether financial and other kinds of support that international organizations provide for CSOs in third countries make a substantive and measurable contribution to the promotion of political and social transformations and to strengthening civil society organizations as democratization agents. There are authors who argue that while foreign donors had a crucial role in the professionalization and institutionalization of CSOs in CEE countries, this influence has not always been accompanied by the de-politicization of these organizations or has even made internationally funded activists more assertive in domestic political conflicts (Ayoub 2013, Cisar 2010, Cisar-Vrablikova 2012). Other scholars, however, challenge the emancipatory potential of democracy assistance (Hearn 2000), claiming that while foreign donors (the EU, in particular) are declaring empowerment and strengthening of civil society as the main purpose of their assistance, in reality the aim is "to build governance and state capacity" (Fagan-Ostojic 2008).

The present article examines the role foreign donors have in the development of civil society organizations working with civic participation and advocacy in Ukraine. Focusing particularly on the developments and transformations of CSOs over the last three years (i.e. after the Euromaidan), it aims to answer the question: How do foreign donors influence Ukrainian CSOs working with civic participation and advocacy, and what are the main obstacles CSOs face on the way to full independence and sustainability? ${ }^{2}$

To answer this research question, I use the concept of democratization and Europeanization "from below." I argue that the issue of democratization from below is more complex than imagined based on positive evaluations and the literature. I claim that while the donors' overall influence may be considered positive, it should be assessed in the context of the political dynamics within Ukrainian civil society. These dynamics include the legal conditions and public opinion as factors contributing to the low sustainability of CSOs. There is a need to adjust the organizational and project structure to Western standards, as at present CSOs are disconnected from the general population. The failure to take these and other factors into consideration may lead to unintended consequences and render previous achievements null.

2 The present article defines a civil society organization (CSO) as any voluntarily union of people and/or legal entities to realize and to protect their rights and freedoms, in particular economic, social, cultural, environmental, and other interests, founded by individuals as defined by the Law of Ukraine "About Civil Groups" (Law \# 4572-17 of 22.03.2012). It uses the term CSOs also for the unions legal entities have founded with the same purposes. The term "non-governmental organizations" (NGOs) is used here as a synonym, unless the article talks about foreign NGOs as specified. 
This article is structured as follows. First, I introduce the background and theoretical framework applied for my further analysis. I discuss then the current context, elaborating in more detail on the domestic and geopolitical conditions, in which Ukrainian civil society organizations have to act. The article concludes with the discussion of theoretical and policy implications.

\section{METHOD}

In the present article, I draw on data collected via interviews, media analysis, and participant observation. During the years 2014-2017, I have conducted more than 30 in-depth, semi-structured interviews in Kyiv and Brussels with employees of NGOs, representatives of donor organizations from Western European countries and the USA ${ }^{3}$, political activists and experts. Among interviewees there were several activists, participants of Euromaidan and the Orange Revolution, employees of NGOs in Kyiv working in the area of human rights and democracy promotion, representatives of the EU delegation to Kyiv, and two Ukrainian MPs. The interviews were 40 to 90 minutes long and covered questions concerning political and social changes in Ukraine, the development of Ukrainian civil society, the work of local CSOs and NGOs funded from abroad, and the influence of foreign actors in Ukraine. In parallel, I have conducted content analysis of major Ukrainian online media (such popular sources as Korrespondent.net, Ukrains'ka Pravda, and Hromadske radio) and the social media of a number of public figures, including Kyiv mayor Vitalii Klychko, and leaders of major political parties. Finally, for more than a year I have been working as a project coordinator for one of the foreign donor organizations in Ukraine, which allowed me to organize participant observation and have access to actors and data required for this study. For the data analysis and explaining outcomes, process tracing has been used to identify the key points (or their absence) in democratic transformations in the country's development and explain the events accompanying them regarding foreign funding and its use by Ukrainian CSOs.

\section{FOREIGN ASSISTANCE IN UKRAINIAN CIVIL SOCIETY'S DEVELOPMENT: BACKGROUND}

Since its independence in 1991, Ukraine has benefited from Western states' substantial support, including - but not limited to - financial assistance. While at the beginning of its existence Ukraine declared approximation with the EU among its foreign politics priorities, relations between these two were based on the vague 1998 EU-Ukraine Partnership and Cooperation Agreement (similar arrangements were offered to all former republics) and the EU did not prioritize Ukraine in its external actions. It was in 2004, after the enlargement round when Ukraine turned into a neighbor country and the Orange Revolution brought to power a seemingly pro-Western, democratic-leaning government that the EU had to devise special policies and instruments for Ukraine (Shumylo-Tapiola 2013). According to foreign experts, over the next decade Ukraine made "remarkable progress toward [the] creation of democratic institutions and strengthening of democratic procedures." (OSCE 2011: 14). For example, already in 2005 Freedom House ranked Ukraine as a "free" country, describing it in 2009 as a "dynamically developing democracy in the region valuing fundamental human rights and freedoms" (OSCE 2011: 14).

3 The present article refers to "donors" and "donor organizations" as to foreign states, international organizations, and foreign NGOs that provide Ukrainian CSOs and civil society activists with non-refundable financial and other forms of assistance for different purposes, overall aimed at the democratization and increased well-being of Ukrainian society. 
Overall, we can define three main stages in the development of Ukrainian civil society and civil society organizations. The first and largest one covers time from Ukraine's independence to the Orange Revolution in 2004. As the 1990s began, the Ukrainian economy was in deep crisis and citizens found it difficult to be engaged in public activities; therefore, the first waves of political participation did not grow into a stable tradition of civil activism (Bekeshkina-Kaźmierkiewicz 2012: 34). In those circumstances, international foundations played a crucial role in the country, providing financial support to a rather weak civil society, to think tanks, human rights organizations or resource centers for other public organizations.

The beginning of the second period is related to the Orange Revolution, a nationwide protest against the presidential election fraud in 2004. Hundreds of thousands of people took part in the protest action demanding another election round and the cancellation of the falsified results of the previous round. This momentum of mass mobilization was referred to as "the apogee of activity and force of civil society in Ukraine" (Bekeshkina -Kaźmierkiewicz 2012: 35) and attracted considerable attention from Western institutions and organizations. The further developments after the victory of the protesters and the coming to power of a pro-EU government were questionable. On the one hand, civil society activists' expectations and hopes for fast democratization, as well as for an improved dialogue between CSOs and state institutions never came true. By the beginning of the next decade, in 2012-2013, Ukraine was in an even deeper economic and political crisis caused, first and foremost, by a highly corrupt governmental structure. At the same time, many foreign donors began to organize their departure from the country or decreased their involvement as the domestic donors activated (Stewart 2009). On the other hand, as noted above, the Orange Revolution made the EU shift the focus of its attention, intensifying its support for the local civil society in Ukraine.

As the approximation between the EU and Ukraine was developing, Russia was increasingly concerned that the political and economic association of Ukraine with the EU would affect Russian economic interests and, perhaps more importantly, the geopolitical balance in the region (DW 2013, Walker 2013). President Yanukovych and his administration ended up in a difficult political situation in the fall of 2013. On the one hand, there was pressure from the Kremlin, while on the other, it seemed impossible for the government to meet certain requirements from the side of the EU. On November 21, 2013, the Ukrainian government issued the decree according to which the preparation for the Association Agreement had to be put on hold. As an almost immediate response, some ten thousand protesters gathered that same day in the central square of Kyiv, which eventually resulted in what is now called "Euromaidan" or the "Revolution of Dignity." As events escalated, the protest camp stayed at Maidan for eight months, during which the Yanukovych regime fell and the former president had to flee the country while the armed conflict erupted in the Eastern part of the country.

Following the events of 2013-2014, foreign donors showed increased interest in supporting democratization processes in Ukraine. Among the most present foreign funders in the country are the U.S. Agency for International Development (USAID), the United Nations Development Programme (UNDP), the National Endowment for Democracy, Open Society's Ukrainian branch, the International Renaissance Foundation, embassies of EU member states, the UK and Canada, and German political foundations (KAS, FES, Heinrich Böll Foundation). After the change in government in 2014, due to a lack of trust in the "old" civic councils, the most 
active civic networks prefer to work independently, building new channels for communication and advocacy at different levels. Some well-known civil society leaders have become members of the National Reforms Council, a consultative body that Petro Poroshenko has introduced to push reforms. Civic experts also populate the Strategic Advisory Groups tasked with helping the government to draw up reformist legislation, strategies, and action plans. A Reform Support Center in the cabinet of ministers has been created to serve as a sustainable connection between the government and civil society initiatives.

After the Euromaidan, new funding programs have been launched to support the democratization efforts in Ukraine. To name a few, ${ }^{4}$ the UK government has channeled $£ 1,630,610$ for civil society development in 2016-2018 to "overcome the impacts of the Russia-backed conflict in the Donbas"; $£ 240,000$ for LGBTrelated research and the same amount for anti-corruption programs in 2016-2017; in 2014 the Obama administration allocated USD seven million to human rights organizations in the country as the Euromaidan emerged (in addition to more than USD 120 million security assistance); Japan has allocated around USD one million since 2014 to civil society development and democratization only through the OSCE and the Council of Europe. Ukraine has also increasingly benefited from the new European Instrument for Democracy and Human Rights (EIDHR) action plan that disposes of a larger budget and places even more emphasis on the need to strengthen the role of civil society as a positive change in the area of human rights and democratization (European Commission 2017).

The legal framework for civil society is mostly open, and the nonprofit status is easy to obtain for CSOs. In March 2017, however, a new law introduced changes into the existing legislation to prevent corruption in Ukraine. The amended Law "About the prevention of corruption" required from people working for CSOs involved in any anti-corruption activity to declare their financial assets the same way the public officials are currently required to. The Law was very vague regarding the definition of organizations whose employees were required to report on their assets and of the conditions under which the declaration was demanded from a CSO. Since 2014, it has been the first obvious barrier the government erected against civil society actions limiting the scope of CSOs' activities and, in fact, creating grounds for corruption. The law was largely criticized by CSOs, as well as by the international community but was nevertheless implemented (UHHRU 2017).

By 2017, the Ukrainian state has remained in quite a complicated situation. After the escape of Viktor Yanukovych, the Russian government made use of the unstable political regime and economic crisis in the country and annexed the Crimean Peninsula, declaring the Autonomous Republic of Crimea a part of Russia. The interim government and later the elected government of President Petro Poroshenko has had to deal with a huge budget deficit, a general economic crisis, and the separatist rebellion in the eastern part of the country, which is significantly supported by Russia. This is accompanied by an aggressive informational war with Russia, which uses multiple sources to broadcast fake information and support pro-Russian groups in Ukraine and its neighborhood, as well as in EU member states.

4 The numbers can be consulted in detail at the UK government official page (https://www.gov.uk/government/news/uk-programmeassistance-to-ukraine-2016-2017); the Obama Administration site (https://obamawhitehouse.archives.gov/the-pressoffice/2014/09/18/fact-sheet-us-support-ukraine); USAID official statistics by country (https://explorer.usaid.gov/cd/ UKR?implementing_agency_id=1); Info on Japan's assistance to Ukraine since 2014 (http://www.ua.emb-japan.go.jp/jpn/ bi_ua/oda/170915_assistance_en.pdf). 
The present section has focused on the events accompanying the development of Ukrainian civil society over the past decade. Taking this information into consideration, I will introduce the theoretical framework and continue with the consequences that these changes and developments, particularly, in relation to foreign assistance, have posed for Ukrainian CSOs.

\section{DEMOCRATIZATION FROM BELOW: THEORETICAL FRAMEWORK}

Growing interest in the impact of international actors on domestic politics made Risse et al. (1999) develop a theoretical framework to study the casual mechanisms by which global rules and international human rights, in particular, spread. In order to distinguish the conditions that lead to the domestic internalization of the international human rights regime, the authors propose a "five-phase 'spiral model' of human rights change which explains the variation in the extent to which states have internalized these norms" (1999: 4). The authors argue that a mandatory condition for the adoption of international human rights by national governments would be the establishment of the rule of law and local structural changes. They understand the process of the internalization and domestic implementation of international norms as a process of "socialization" and suggest three groups of causal mechanisms that endure it: instrumental adaptation and strategic bargaining, moral consciousness-raising and argumentation, and institutionalization and habitualization. While each of these groups becomes more important under different conditions, at the earlier stages of norms internalization, according to Risse, instrumental adaptation prevails (1999: 6). The authors focus on the important role of Western democracies to promote the international human rights regime to "Third World countries" and claim the responsibility Western states have to prevent human rights violation in Africa and Latin America through transnational advocacy networks and to impose and constitute the rule of law in the regions concerned. Though hardly is it possible to disagree with Risse et al.'s statement of the importance of the practical implications of the theoretical model offered for a "more effective use of the time and resources of transnational human rights networks", the work quoted has been fairly criticized for being Eurocentric and overlooking the agency role of the national norm-takers and norm-makers (Acharya 2004).

The actions taken by local actors with the help of EU assistance, such as civil society organizations' electoral support for pro-European political parties, shaming demonstrations, conferences, and education events. were named as "Europeanization from below." In the literature on norm and policy diffusion, the external support of civil society through financial, technical and political assistance has been defined as the "capacity building mechanism" international actors are applying to domestic actors (Börzel-Risse 2012: 7). Börzel and Risse comment that this mechanism presents an additional level of foreign actors influencing change. They claim, however, that in the case of the EU this mechanism would be effective only for the accession candidates combined with European conditionality for the countries aspiring for EU market access. The mechanism is not expected to work effectively in more distant areas where the EU has no strong economic or political interest (2012: 7).

In the literature on Europeanization, capacity building is not usually considered a separate mechanism used by the European Union and is briefly described only by Börzel and Risse (2012). I argue, however, that it is 
necessary to distinguish capacity building from other mechanisms most often referred to, namely conditionality and persuasion. First, this mechanism targets different actors and levels of domestic political structures. It is also different from persuasion or socialization as it implies a specific way of interaction and influence exercised upon domestic societies. The local political actors, such as civil society organizations, individual activists, artists, and academics are getting financial resources, technical support, and educational assistance for incentives and events aimed at promoting Western norms and values and building a "democratic" society.

Instead, studying foreign influence on democratization in the member states of the Association of Southeast Asian Nations, Acharya (2004) suggests a localization framework that presents an explanation for the fact that a state or regional union may accept and adopt one norm while fully rejecting another. According to Acharya, it makes sense to replace the term "norms diffusion" that implies that local norm-takers are passive by the term "norm localization" that implies more dynamism. The contribution of Acharya's framework consists in turning local actors from passive norm-takers or learners into dynamic agents that carry out "norm selection, borrowing and modification in accordance with a preexisting normative framework to build congruence between that and emerging global norms" (2004: 269). It can be further used to specifically explain the behavior of nonWestern states that receive norms and their agency role.

Koo and Ramirez (2009) point out the world's saturation with numerous human rights organizations, treaties, conferences and publications as the main factor positively influencing the adoption rate of human rights standards. This development, according to the authors, is closely related to the "rise and expansion of the human rights discourse at the national level" (2009: 1342). However, it is important to make a distinction between the mere adoption of the documents and what the authors define as the national incorporation of international human rights standards (Koo-Ramirez 2009: 1323). Since if a national government ignores global human rights (HR) treaties and regimes, it normally leads to the expression of disgrace and illegitimacy by the world polity, Koo and Ramirez suggest that most states will be more likely to adopt international standards for human rights. However, when it comes to countries with lower democratic profiles and high costs of the implementation of HR regimes, the findings show that these states will be more enthusiastic to implement treaties that carry a symbolic meaning and will try to avoid more demanding protocols with stronger pressure towards compliance. The simple adoption of HR standard does not, therefore, directly facilitate the establishment of a national HR regime and the creation of a more positive human rights record (2009: 1342-43).

The growing presence of the USA and the EU against the backdrop of the conflict with Russia and a deep political and economic crisis has certainly brought additional opportunities for CSOs, including the funding options and, more importantly, the expansion of networking opportunities. Democratization from below, therefore, should not be overlooked when examining transformation in third countries. The developments accompanying the evolution of civil society in CEE countries over the last two decades as well as the interaction between foreign actors and civil society groups there show that foreign donors' capacity-building approach deserves more attention than it used to get. The empirical and analytical parts of this article aim to address this gap. 


\section{BRINGING POSITIVE CHANGE: NEW POLITICAL ACTORS, INTERNATIONAL COOPERATION AND} PROFESSIONALIZATION OF UKRAINIAN CIVIL SOCIETY

In 2017, Freedom House referred to civil society in Ukraine as to the "the strongest element in Ukraine's democratic transition" (Freedom House 2017: 2). Indeed, mass mobilization during the Revolution of Dignity resulted in the awakening and birth of numerous civil society organizations, which, after the government had changed, turned into a persistent driver of reforms for democratization and social change. The existing legal framework, created in 2012 and improved in 2016, for civil society organizations may, in principle, be characterized as open and supportive, especially compared to other post-Soviet republics like Russia or Belarus. "Open" means that the government does not prevent the establishment of NGOs, apart from a few exceptions does not set obstacles for most of the legitimate NGO events and activities, and it is quite easy for an organization to be registered as non-profit.

This section discusses the most important, argument for the sake of this article, namely the changes related to institutionalized civil society activism in Ukraine after the Revolution of Dignity, focusing first on the positive transformation and then reflecting more on the challenges NGOs are facing. The concluding section will tackle the role foreign donors play both in the achievements and challenges of Ukrainian civil society, and suggest the possible implications of this impact.

\section{Emergence of new political actors among the protest participants}

One of the reasons why the international donor community see the Revolution of Dignity as having positive consequences for empowering of Ukrainian civil society was the emergence of new political actors among the protesters. During the previous two decades, Ukrainian political elites had mainly been representatives of either the older generation who started or made their career during Soviet times, or businessmen who decided to expand their influence into the public sphere. Surveys showed that neither group enjoyed a particularly high level of trust from the side of population (DW 2012). As a result of the government collapse and President Yanukovych's flight from Ukraine in 2014, several Ukrainian political parties who had been particularly active at Euromaidan or even won the popular vote shared most seats in parliament and government. Among them there were the "Petro Poroshenko Bloc" (Petro Poroshenko became the newly elected president), the "People's Front" of Arsenii Yatsenyuk, "Samopomich" (Self-help) Party, the "Civil Position Party," headed by the former minister of defense Anatolij Hrytsenko, and the "Batkyvshchyna" (Motherland) Party headed by former Ukrainian prime minister Yuliya Tymoshenko.

It is particularly relevant that personalities active in the Maidan protests and expressing active proWestern or pro-EU positions have appeared on the major party lists and in the Cabinet. Among the new generation of Ukrainian politicians and public servants we have, among others, young MPs Serhii Leshchenko and Svitlana Zalishchuk (both from the Petro Poroshenko Bloc) or Deputy Minister of Internal Affairs of Ukraine, Anastasiya Deeva. The common characteristic of this new generation of politicians is that they maintain tight links with the West: Western education, active participation in international conferences, workshops, training and various forms of knowledge exchange. Unsurprisingly, these leaders express ideas that tend to be approved 
by the international organizations and are positively seen by foreign donors, compared to those of the previous political elites. Among the examples of the "new" political behavior, the support for the Equality March in Kyiv is noteworthy. Svitlana Zalishhuk even appeared in the photos as part of the media-campaign that had the slogan "It's always time for human rights" to support LGBT pride (National LGBT portal of Ukraine 2015). The member of the same party, Serhii Leshchenko, posted on his Facebook page:

Leshchenko is supporting the gay parade. Not any gay parade but the Kyiv Pride. Because these are human rights. And non-discrimination - not only at the domestic level, but legally provided - is a part of mandatory requirements for Ukraine to get a visa-free regime with the EU. Do you want to enter Schengen without a visa? Respect the minorities' rights, both ethnic and sexual minorities (Leshchenko 2015, the author's translation).

The emergence of such new political actors turned out to be one of the reasons for opening space for political participation for the groups that the wider society had largely overlooked or marginalized before Euromaidan. Among these groups, there are the LGBT community, feminists, environmentalists, urbanists, and others. These, so-called "new social movements" were much less visible in Ukraine before Euromaidan and even less during the first decade of Ukrainian independence. Now, as Ukraine has become more attractive for foreign aid donors in different sectors, such organizations have been receiving funding as well as technical and informational support. It is sufficient to take a look at the projects funded in the last several years by the EIDHR, USAID, donor organizations of EU member-states and others, including LGBT organizations, organizations working for gender equality, the non-government civic open tech sector, independent media, and anti-corruption organizations. Most of them have never enjoyed state support and would be unable to function as professionalized and institutionalized CSOs, which makes foreign donors' support an important precondition of their work and existence.

The professionalization and institutionalization of Ukrainian civil society can be seen as one of the positive consequences of increased international support. Apart from funding, many donors offer wider support, including various workshops (on writing grant application, advocacy, lobbying, project management, etc.), trainings, study visits abroad, participation in conferences and round tables, integration of external experts (for example, a GIZ expert from Germany has been working for LGBT parents' organization in Kyiv for two years), leadership development, working groups, online support of experts, and other ways for CSOs in a targeted country. An interviewee, who is a representative of a CSO working in the education reform sector, commented that such kind of help is not less helpful as it raises the quality of a project's output and leads to a more competent approach to further funding applications. Correspondingly, it is not surprising that the organizations that once received foreign funding and have a positive record of relations with foreign donors benefit from further contributions more frequently and in larger quantities.

\section{International cooperation and transnational activism}

Euromaidan and further events provided Ukrainian CSOs with much more opportunities for involvement into international cooperation and transnational activism. As the interest in transformations taking place in Ukraine has been growing, Ukrainian experts and civil society activists have been increasingly invited to a 
number of international events adding to the visibility of local CSOs and creating stable transnational links. For example, among others, in the last two years the German-Ukrainian Academic Society and the Munich Kyiv Queer (LGBT network for German and Ukrainian activists) have been founded, while Turkish and Ukrainian civil society groups have organized a number of joint projects for Crimean Tatars. Apart from visibility, this provided Ukrainian CSOs with new tools for promoting transformation and changes in the country appealing to the international community and using international actors such as the EU or its bodies as a point of reference to influence local political actors. For example, as the Ukrainian government faced the need to comply with the conditions of the Visa Liberalization Package in 2014-2016, civil society activists re-framed their demands presenting them as EU requirements that Ukraine has to comply with to be granted a visa-free regime. In some cases, as in the adoption of the anti-discrimination amendment to the Labor Code and the National Strategy for Human Rights including a number of provisions that would have been impossible in Ukraine some years ago (such as, for example, the same sex marriage project proposal), this strategy proved to be quite effective.

The discussion above confirms the argument voiced by social movements and the civil society literature that foreign donors and, particularly, the EU's assistance have some positive effect on strengthening domestic civil society and democratization from below. Having acknowledged all these positive developments and others not listed here, as well as the indirect benefits of foreign funding for CSOs in third countries, this article will not focus on some weaker points in this cooperation and reflect on challenges the civil society organizations in Ukraine are facing. While it would be wrong to claim that there are causal relations between foreign aid and problems of Ukrainian CSOs, I suggest that existing policies and practices do need certain adjustments and improvements, which would positively influence the social and political impact of the CSOs supported by foreign donors.

\section{FOREIGN ASSISTANCE TRADEOFFS}

In this section of the article, I focus on the so-called tradeoffs coming with foreign assistance. Some of the points I make, like the project culture problem and the disconnectedness of professionalized CSOs from grassroots activists have already been noted in the literature on civil society activism in developing democracies (Kuzmanovic 2010, Cisar-Vrablikova 2012), displaying commonalities of civil society growth and development in the CEE region and European neighborhood. Others, as low sustainability and relations of CSOs with national political parties, are often addressed in the recent scholarly debate and, therefore, may deserve special attention.

Project culture has become an integral part of any professionalized CSO's life practice. To be able to survive and afford to pay full or part-time staff, most organizations have to apply for foreign donors' funding on a regular basis. As donors usually prefer not to cover the full scale of an organization's activity, focusing either on particular projects or paying for particular staff or, sometimes, for office space, it is usually necessary to apply to several organizations at the same time. The increasing competition among the organizations also requires diversification of risks and applications. The first obstacle to the stable functioning of most CSOs is the rather complicated application process. To start with, the applications in most cases should be made in English, 
which requires that the organization have advanced speakers of English on their staff. Then, the application procedure follows a particular way, which varies from donor to donor. This phenomenon has been discussed by Kuzmanovic (2010) as "project culture": the applications for funding by international organizations are to be carried out in the form of projects, which include a detailed conceptual part, budgeting, description of step-by-step actions, staff structure, adjustment of the project description in the correspondence with the CFA requirements, and other technicalities. This is a time and energy-consuming process, which requires certain skills and qualifications. Therefore, as Kuzmanovic points out, some CSOs that can afford it hire a special person whose job is to search for funding opportunities and to write applications for each call. In the interviews I conducted with Ukrainian NGOs and from what I observed working in the area, most organizations successful with obtaining funding on a regular basis had a person dealing particularly with drafting projects and looking for funding opportunities. Commenting on the complexity of the application processes, my interviewees admitted that the next application always requires less effort in the application process and that it is usually easier to obtain funding if you have already carried out and reported on a number of successful ones. As the cost of the project is not usually covered in full by one donor, organizations often have to find their own means to bear the difference. Typically, this is not a problem for bigger organizations with funding from many sources, permanent staff, and office space. However, it seriously limits smaller or younger organizations' chances of accessing financial resources.

The competition for the recourses as well as some organizations' repeated success with obtaining funding often seems to lead to a disconnectedness of professionalized civil society organizations from those defining themselves as grassroots. This disconnectedness can be observed, for example, in following open debates between activists on different social media platforms or in personal interviews both with the activists and representatives of donors. Obviously, one of the stumbling blocks in the debate is which organizations the donors are ready to fund. However, the disconnection goes further than that and relates to strategic goals, tactics of resistance and methods. One of the examples that provoked hot discussions in Ukrainian civil society was the equality marches for the rights of LGBT people in Kyiv in 2014 and 2015, which were largely criticized by grassroots organizations as neoliberal events sponsored by the West. They also felt that it was imposed at the least appropriate time when the country was in a war conflict with Russia, when additional provocations were counterproductive. The situation can be best illustrated by the quote from an interview I conducted with a representative of the EU delegation to Kyiv (personal communication, August 2014) who said that "the EU does not demand from Ukrainians a pride parade, it is the Ukrainians who ask for it." This quote seems to describe the general situation in which the ideas and aspirations of professionalized civil society, which is still somewhat elitist in Ukraine, are often generalized as if they reflected the wider public opinion.

\section{Low sustainability}

As noted above, professionalized civil society in Ukraine may, to a certain extent, be defined as "imported" or "copied" from the Western model. While there were dissident and feminist movements in the Soviet Ukraine, the institutionalized network of civil society organizations in the country today has been largely influenced by international organizations, donors and partner-NGOs. While this situation can be explained 
mostly by the absence of our own previous experience, another more practical explanation of the trend is that foreign donors are the major, if not the unique, source of existence for organizations acting in the area of civic participation and human rights advocacy, transparent governance, open data, and anti-corruption activity. Some authors have widely criticized the high level of dependence of foreign donors in CEE countries (SpinaRaymond 2013) in relation to project culture, as well as due to the allegedly imposed neoliberal values and depoliticization of social movements in third countries.

Some countries have had negative experience with European neighborhood (Russia and Turkey), and even EU member states, such as Poland and Hungary where the governments have developed the politics of securitization aimed at limiting the influence that foreign actors have on domestic politics through financing of NGOs and social movements. Russia is an extreme case, where in 2012 the notorious Foreign Agents Law was implemented, causing the immediate shutdown of 27 NGOs. In 2012-2016, 148 organizations were included in the "foreign agents" list, usually the ones protecting human rights, such as the Open Society Foundation founded by George Soros (Human Rights Watch 2017). Unsurprisingly, these organizations were either critical of the government or supporting activists and citizens suffering from violations of their rights by the Kremlin (Amnesty International 2016). Currently the main concern of Polish NGOs is the intention of the national conservative government to centralize funding through a National Center for Civil Society, subject directly to Prime Minister Beata Szydlo. If this happens as it is promised, it will pose the risk that foreign funds may be directed only to NGOs hat demonstrate a pro-governmental position. The current developments may make foreign donors seek new ways of supporting NGOs, as having to deal with public institutions, many Polish organizations currently find it too cumbersome to apply for EU funding. Considering all this, the issue of sustainability emerges as critical for Ukrainian CSOs as well. The current government presents itself as very pro-European and it is highly unlikely that it will soon change its course towards restrictions copying Russian politics. However, the 27-year history of Ukraine is full of ups and downs of democratic transformations. Therefore, some activists consider the importance of being able to survive as an organization without western assistance or with drastically reduced support. One of the ways to solve this issue would be to stimulate donations from the side of the population and increase the share of volunteers' work. The solution is difficult though, as an additional issue related to NGOs supported by Western funds is that the population's awareness of them is highly insufficient.

The last point, low understanding by average citizens of the work the CSOs are doing can be mostly explained by two factors. First, there is a genuine problem typical of the CEE context that "fake" NGOs are created and registered to be used by corrupt public officials for channelling funds governments obtain for civil society support. As my interviewees from donor organizations explained, these cases were much more popular at the earlier stages of "democracy-building" in Ukraine and are less frequent these day due to an increased level of transparency and accountability from the side of the government, as well as due to donors' preference for working directly with civil society organizations and activists themselves. Even though the situation has much improved, the population's general distrust of the corrupt government partially remains associated with the third sector. Second, there is the prevalent discourse in the Ukrainian public sphere that many NGOs supported by the West are nothing but "grant-eaters" distant from the "real world" spending Western money 
on their own needs. It is difficult to identify where or who this discourse originated from, but I have regularly heard the term "grant-eater" in the interviews and conversations with people professionally engaged with the third sector in Ukraine. One of the activists with more than 10 years of experience said in her interview:

For example, when my mother who works in the public sphere as a doctor, and earns some 250 Euros a month, hears on TV that people in NGOs receive 3000 dollars... of course, she feels indignation. However, first of all, there are no such salaries, second, you have to compare how much the people who work in this NGO do and what qualifications are required..." (personal communication, Kyiv, 10.05.2017).

Ordinary citizens' concern about NGOs abusing access to foreign funding and the use of "grant-eater" as a common term were given by numerous interviewees. In turn, interviewees either expressed how insulted they felt by these attitudes or showed some sad irony, as many of them are poorly paid and work long hours for free, donate to the projects themselves, and are far from the virtual image of a rich NGO officer spending vacations abroad.

To summarize, positive results of the presence and support of the foreign donors as described in the previous section confirm the existing literature on Europeanization from below or bottom-up democratization. Indeed, financial and technical support allows CSOs in Ukraine to gain more space for public and political participation, visibility, and, therefore, also popular support. Similarly to Poland described by Ayoub (2013) and the Czech Republic (Cisar 2010), Ukrainian civil society has become more professionalized, involved in transnational activism and cooperation, and has reached a new level of political participation, building alliances with new political actors and groups. At the same time, this section shows that there are certain issues both scholars and foreign donors overlook, such as the disconnectedness from grassroots organizations, low sustainability and the dependency of CSOs on foreign donors. These problems are partly related to the low level of the population's trust that most CSOs still experience. The fact these problems are frequently ignored can be explained by the donor organizations' general lack of understanding of the complexity of the domestic environment where they are functioning. This lack of understanding and the reluctance on the part of donor organizations to give up their standard approach to the region leads to an obvious decrease in the efficiency of democracy promotion. In addition, in some cases, it may even produce some unexpected negative outcomes.

\section{CONCLUSION}

The present article is engaged with civil society development in post-Euromaidan Ukraine, focusing on civil society organizations engaged with civic participation, democratic governance, and human rights. Civil society, which before Ukraine obtained its independence existed mainly in a highly unstructured underground form, and which was still under-developed in the first two decades of the country's existence, first gained additional attention from Western states and donor organizations after the so-called Orange Revolution in 2004, and was even more in the limelight after the Revolution of Dignity in 2014. The events of Euromaidan demonstrated to the world that Ukraine possesses a very dynamic and vibrant civil society with obvious potential for mobilization, civic participation and civic consciousness. This as well as the worsening situation with the presence of Russia in the region together with the shifting geopolitical power balance prompted Western states to re-distribute their resources, redirecting more to the construction and support of the young 
Ukrainian democracy. This article shows how the shift in Western donors' strategies and priorities for Ukraine was taking place as domestic changes were evolving in the country.

The empirical research in Ukraine demonstrates that, in line with the literature, the funds invested into democratization on the level of civil society do bear fruit. Ukrainian civil society organizations demonstrate growing levels of institutionalization and professionalization. As reflected by the European Commission and USAID reports, a growing number of Ukrainians involved in civic activism attend various educational events, travel to the EU and the USA for experience exchange, training sessions with activists, workshops, conferences, and other networking and learning activities (USAID 2016, European Commission 2017a). Also, again in line with the existing literature, my interviews with CSO activists who benefit from Western support have revealed that even the political appeal to the argument of approximation with the European Union and stressing the need to comply with "European values" made a positive difference when lobbying their interests. This became particularly effective when the Revolution of Dignity and mass mobilization opened the space for CSOs' political participation. The temporary lack of strong political groups in power gave civil society the momentum for action and for pushing for change, and even if this was only for a short moment, it made its impact. Moreover, this temporary vacuum, a turbulent political environment with no effective government, allowed new political actors to step up and gain popular support. They were typically younger, had no "communist" or "oligarchic" past, but had a Western education which they had received abroad, and cherished more progressive values. In these circumstances, the foreign support fell on much more fertile ground than any time before, particularly with the Yanukovych regime.

On the other hand, this article shows the problems in the way foreign funding is allocated and foreign donors act in the country, looking for potential beneficiaries of funding, distributing their support and monitoring the projects in process. Among the issues I suggest addressing critically are the so-called project culture and the preference for professionalized over grassroots civil society, in some cases a lack of understanding of domestic dynamics by the persons in charge of control and the monitoring of projects. As a result of these phenomena as well as of the population's persistently low level of trust in civil society organizations, the low sustainability of CSOs also needs attention. This last issue, namely Ukrainian civil society organizations' presently extreme dependency on foreign donors' financial but also political and technical support is seen as the most problematic aspect in need of an immediate solution. This article considers the dependence on foreign donors dangerous for the further development of civil society in Ukraine for two reasons. First, there is a political risk similar to what some other CEE countries are facing where the government has put pressure on civil society, restricting the access CSOs have to foreign funding. This has caused that space for action and political participation has been shrinking. The newly introduced amendment to the "About the Prevention of Corruption Law" is an example of such pressure. While in the present conditions of conflict with Russia the Ukrainian government is highly unlikely to reject Western support, the dependency on funding granted substantially shapes the strategies of civil society organizations in accordance with the priorities international donor organizations set for them. In certain cases, foreign aid may cause such unintended consequences as internal conflicts, hidden agendas and strained relations between civil society groups and organizations, such as inertia or even a backlash against targeted groups. The solution could be to push for the development of 
national legislation and more favorable conditions for a national business sector to act as a potential donor for the Ukrainian CSOs, as well as to introduce tax instruments encouraging Ukrainians to relocate part of their taxes to the non-governmental sector.

Are foreign donors friends or foes then? It would be difficult to underestimate the extent and significance of foreign donors' support for the growth, institutionalization and professionalization of civil society in Ukraine. At the same time, the fact that this importance is not decreasing and remains stable both for older and for newly emerging organizations demonstrates Ukrainian civil society's high level of persistent dependency on foreign donors. Not only does such dependency present a potential threat to the long-term potential existence and survival of Ukrainian civil society as a dynamic driver for political and social change, but mostly due to the foreign donors' lack of understanding of the local context, may also lead to unintended consequences worsening the targeted groups' conditions. 


\section{REFERENCES}

Acharya, A. (2004) How Ideas Spread: Whose Norms Matter? Norm Localization and Institutional Change in Asian Regionalism. International Organization, 58, 239-275. https://doi.org/10.1017/S0020818304582024

Amnesty International. (2016) Russia: Four years of Putin's 'Foreign Agents' law to shackle and silence NGOs. Available at: https:// www.amnesty.org/en/latest/news/2016/11/russia-four-years-of-putins-foreign-agents-law-to-shackle-and-silence-ngos/ [Accessed: 18-06-2017].

Ayoub, P. M. (2013) Cooperative transnationalism in contemporary Europe: Europeanization and political opportunities for LGBT mobilization in the European Union, European Political Science Review, 5, 279-310, https://doi.org/10.1017/ S1755773912000161

Bekeshkina, I. - Kaźmierkiewicz, P. (2012) Making Ukrainian Civil Society Matter. Enabling Ukrainian NGOs to absorb international assistance. A review of capacity gaps and needs for institutions support. Warsaw: Fundacija Instytut Spraw Publicznych.

Börzel, T. A. - Risse, T. (2012) From Europeanisation to Diffusion: Introduction. West European Politics, 35 (1), 2-19, https://doi.org/10 $.1080 / 01402382.2012 .631310$

Cisar, O. (2010) Externally sponsored contention: the channeling of environmental movement organisations in the Czech Republic after the fall of Communism. Environmental Politics, 19 (5), 736-755, https://doi.org/10.1080/09644016.2010.508305

Cisar, O. - Vrablikova, K. (2012) Transnational activism of social movement organizations: The effect of European Union funding on local groups in the Czech Republic. European Union Politics, 14 (1), 140-160, https://doi.org/10.1177/1465116512456311

DW (Deutsche Welle) (2012) Ukrainians' trust in politicians hits new low. Available at: http://www.dw.com/en/ukrainians-trust-inpoliticians-hits-new-low/a-16236399 [Accessed: 19-04-2017].

DW (Deutsche Welle) (2013) Russian threats block Ukraine-EU trade deal. Available at: http://www.dw.com/en/russian-threats-blockukraine-eu-trade-deal/a-17244844 [Accessed: 01-12-2017].

DW (Deutsche Welle) (2016) Poland's government wants to control NGOs. Available at: http://www.dw.com/en/polands-governmentwants-to-control-ngos/a-36609126 [Accessed: 03-12-2017].

European Commission (2017) Democracy and Human Rights. What is EIDHR? Available at: http://www.eidhr.eu/whatis-eidhr [Accessed: 01-06-2017].

European Commission (2017a) Association Implementation Report on Ukraine- Joint Staff Working Document. Available at: https:// eeas.europa.eu/headquarters/headquarters-homepage/35604/association-implementation-report-ukraine-joint-staffworking-document_en [Accessed: 01-12-2017].

Fagan, A. - Ostojic, M. (2008) La Serbie post-Milosevic. The UE and Civil society in Serbia: Governance rather than politics. Balcanologie, 11 (1-2) Available at: https://balkanologie.revues.org/1393 [Accessed: 19-04-2017].

Freedom House (2017) Nations in transit. Ukraine. Available at: https://freedomhouse.org/report/nations-transit/2016/ukraine. [Accessed: 05-03-2017].

Hearn, J. (2000) Aiding democracy? Donors and civil society in South Africa. Third World Quarterly, 21 (5), 815-830.

Human Rights Watch (2017) Russia: Government vs. Rights Groups. The Battle Chronicle. Available at: https://www.hrw.org/russiagovernment-against-rights-groups-battle-chronicle [Accessed: 01-12-2017].

Koo, J. W. - Ramirez, F. O. (2009). National Incorporation of Global Human Rights: Worldwide Expansion of National Human Rights Institutions, 1966-2004. Social Forces, 87 (3), 1321-1353

Kuzmanovic, D. (2010) Project Culture and Turkish Civil Society. Turkish Studies, 11 (3), 429-444.

Leshchenko, S. (2015, June 3) [Facebook update]. Available at https://www.facebook.com/leshchenko.ukraine/posts/8564965944210 10?pnref=story [Accessed: 20-04-2017].

Lozovsky, I. (2016) Why Ukraine's desperate struggle gives me hope. Censor.net, 22.09.2016. Available at http://en.censor.net.ua/ resonance/407244/why_ukraines_desperate_struggle_gives_me_hope [Accessed: 04-04-2017].

National LGBT-portal of Ukraine. (2015 May 27) Svitlana Zalishchuk pidtrymala provedennya y Kyyevi gay-praydu (Svitlana Zalishchuk supported gay pride in Kyiv) Available at: https://lgbt.org.ua/news/show_2853/ [Accessed: 04-04-2017].

OSCE (2011) International practices of confidence building - Measures between the states and civil society. Available at: http://www. osce.org/ukraine/86185?download=true [Accessed: 01-06-2017].

Risse, T. - Ropp, S. C. - Sikkink, K. (eds.) (1999) The Power of Human Rights: International Norms and Domestic Change. Cambridge: Cambridge University Press.

Shumylo-Tapiola, O. (2013) Why Does Ukraine Matter to the EU? Carnegie Europe. Available at: http://carnegieeurope. eu/2013/04/16/why-does-ukraine-matter-to-eu-pub-51522 [Accessed: 04-04-2017]. 
Spina, N. - Raymond, C. (2013) Civil Society Aid to Post-Communist Countries. Political Studies, 62 (4), 878-894. https://doi.org/10.1111/1467-9248.12081

Stewart, S. (2009) NGO development in Ukraine since the Orange Revolution. In Juliane Besters-Dilger (ed.) Ukraine on its way to Europe. Interim results of the Orange Revolution. Frankfurt am Main: Peter Lang Verlag, 177-194.

UHHRU (2017) Vidkryte zvernennya do Prezydenta Ukrajiny shchodo zakonu pro vnesennya zminy do statti 3 zakonu ukrajiny pro zapobihannya koruptsiji [Open Call to the President of Ukraine Concerning the introduction of changes to the Article 3 to the Law About prevention of Corruption]. (27.03.2017). [Accessed: 03-11-2017].

https://helsinki.org.ua/appeals/vidkryte-zvernennya-do-prezydenta-ukrajiny-schodo-zakonu-pro-vnesennya-zminy-do-statti-3-zakonuukrajiny-pro-zapobihannya-koruptsiji/

United Nations Ukraine (2017) Neal Walker: Why international conference on support for Ukraine makes sense. Available at: http:// www.un.org.ua/en/information-centre/news/3493-n-eal-walker-why-international-conference-on-support-for-ukraine-makessense [Accessed: 14-04-2017].

USAID (2016) 2016 Civil Society Organization (CSO) Sustainability Index for Central and Eastern Europe and Eurasia. Available at: https://www.usaid.gov/europe-eurasia-civil-society [Accessed: 01-12-2017].

Walker, Sh. (2013) Ukraine's EU trade deal will be catastrophic, says Russia. The Guardian. Available at: https://www.theguardian.com/ world/2013/sep/22/ukraine-european-union-trade-russia [Accessed: 01-12-2017]. 